\title{
Book Selection-from Teachers College to University
}

The transformation of a teachers college into a state university with the inevitable changes in educational aims and emphasis poses problems for the librarians. Research facilities must be increased to meet the needs of expanding graduate programs. Simultaneously basic book and periodical collections must be built to form a sound foundation for improving the instructional program. In these circumstances, it becomes the librarian's responsibility to formulate selection policies which will inform the faculty of his new objectives and invite their cooperation.

A cation during the last decade or so has been the rapid change in status and objectives of the teachers colleges. Beginning as normal schools, they have become successively multipurpose state colleges, and more recently state universities. Larger enrollments, new curricula, and the emphasis on excellence in education inevitably require expanding facilities for study and research. To meet this need, the librarians of these schools have been forced to re-examine their selection policies and to devise means for building up their meager resources as quickly as possible.

Traditionally, instruction at teacher training institutions has been textbook oriented with the library often little more than an overgrown reserve reading room. On far too many campuses, the legacy of this kind of educational philosophy is a collection of multiple copies, textbooks, and worthwhile volumes all jumbled together indiscriminately in the

Dr. Clarke is Assistant Director of the Wisconsin Graduate Library School. Mr. Cooklock is Director of Libraries at Wisconsin State University in River Falls. stacks. Under these circumstances, basic collection building must go on simultaneously with, and even assume a certain priority over, current selection. To avoid aimless and random purchasing, the administrative officers have encouraged and in some cases even required their librarians to draw up a well-formulated acquisitions policy.

To whom shall the librarian turn for suggestions of titles to improve the basic collection? In many colleges the senior professors who joined the faculty when the institution was still essentially a normal school have little interest in the library. Far too many of the younger men, brought in recently to teach the expanding list of academic courses, are subject specialists with a narrow view of their discipline. They specialized at graduate school and they know the items needed for their specialty, but these books may have no relevance to the courses they now teach. Moreover, they often lack the bibliographic knowledge and teaching experience necessary to analyze the library's holdings effectively, and if they botch the job of evaluating the book collection how can their sug- 
gestions for improving it have any value?

Fortunately, we still find on nearly every campus a few real bookmen with broad intellectual interests and knowledge. Librarians cultivate and esteem these professors as rare but precious individuals who can supply them with invaluable bibliographic insights. The controlling and shaping influence on the collection, however, must be exercised by the librarian himself since the budgetary responsibility rests on his shouders. The faculty lays out the educational terrain and suggests guidelines as to which direction the curriculum will go. Using dependable printed bibliographic lists, the librarian then tries to build the roads and bridges for the students to follow.

A search for valid "principles of book selection" that will stand up to the pitiless light of faculty criticism can be an unnerving experience. It seems axiomatic that the foundation for the library's expanding collections ought to be "the basic books that have stood the test of time and have helped to mold world opinion." The assumption here is that at certain times men of genius have discovered turning points in man's knowledge which increase his understanding through totally new concepts or through brilliant syntheses of existing knowledge. One thinks immediately of the pivotal influence of Thomas Malthus, John Stuart Mill, Emile Durkheim, Auguste Comte, and others on the development of the social sciences. We feel that college students should be turning to their works spontaneously, either as a part of their course work or due to faculty recommendations. Without the historical approach to the social sciences, the student will feel trapped ten years hence by discovering that very little of what he learned in college is any longer applicable. Yet a recent survey of fifty social science "classics" in fifteen undergraduate libraries (both liberal arts schools and state colleges) reveals that
18 per cent of these important titles were not held at all and 23 per cent did not circulate more than once in five years. The conclusion seems to be that much of the reading done by students in these disciplines is not in the field of the classics but in the many-faceted literature of the present. An equally important explanation, perhaps, is the availability of paperback "books of readings" which contain extracts from these writers. Many instructors prefer to assign this convenient type of material as supplementary reading for their large introductory classes.

In the field of literature, a basic desiderata list should include the works of standard authors, critical studies, and literary histories-all in the best editions. These books are the foundations of our culture and the backbone of the library's collections. In most libraries new editions of standard authors are selected almost automatically without regard to student or faculty demand. Use studies again seem to indicate, however, that this may not be the wisest or most economical method of collection building. Even such respectable writers as Joseph Conrad, James Fenimore Cooper, and Robert Louis Stevenson are frequently uneven in quality; only a few of their works are still read these days. A book needs more than a famous author to attract readers.

Current heavy usage is not, of course, the sole or even the principal consideration for book selection. These basic texts and primary works of literary criticism and literature merit a place on our shelves regardless of faculty or student interest. Patently, a student cannot be educated or enlightened by an important book he has not yet read. If we fail to select the "classics" in each discipline and neglect publicizing their presence in our library, they might as well not exist for him. To justify selecting large numbers of books on our own initiative 
without regard to faculty demand, librarians can only emphasize their potential usefulness and continuing value for study and research.

In many respects the most reliable device in basic collection building is the use of checklists and subject bibliographies reviewed and supplemented by recommendations from faculty specialists. There are a variety of such works ranging from "Shaw's List" and the "Lamont Catalog" to specialized bibliographies prepared by authorities in the field. Particularly helpful for professional education has been Katharine Stokes' Book Resources for Teacher Education: a Study Toward the Compilation of a Core List (1959). This list should be supplemented by the annual bibliographies in the NEA Journal and School and Society. Of more recent vintage is W. W. Brickman's bibliographical chapter in Sources of Information in the Social Sciences (Bedminster Press, 1964), containing over two hundred carefully selected titles. Similar lists for undergraduate libraries exist in such diverse disciplines as mathematics, physics, English literature, and American studies.

Having assembled a strong foundation of standard works, the next step is to acquire the periodicals, society publications, documents and manuscripts essential for the research needs of an expanding university. In this more advanced state of library development, even the most knowledgeable librarian will need all the help and professional advice available from faculty and subject specialists. He should act like a bibliographic sponge soaking up clues about educational goals, graduate student book needs, and faculty research interests wherever he can. Obviously, working closely with individual faculty members requires considerable time and patience from the librarian but the results will prove well worth the effort.
There is no gainsaying the fact that the only strong research collections with noted quality are those built in depth by faculty and librarians working together as colleagues.

A new program offering graduate instruction and research in English linguistics for secondary school teachers illustrates the advantages of collaborating with a subject specialist. As a starting point the chapter references and notes can be checked in such standard textbooks as W. N. Francis' The Structure of American English (Ronald Press, 1958), and Stuart Robertson's The Development of Modern English (PrenticeHall, 1954). Next the bibliographies might be checked in a number of secondary works, including such introductory guides as W. P. Lehmann, Historical Linguistics (Holt, Rinehart, Winston, 1962); Morton Bloomfield, A Linguistic Introduction to the History of English (Knopf, 1963); and more recently, Mario Pei, Invitation to Linguistics (Doubleday, 1965). Going still further, titles of books and periodicals of narrower scope can be gleaned from such specialized works as Paul Garvin, Natural Language and the Computer (McGraw-Hill, 1963); and Sol Saporta, Psycholinguistics (Holt, Rinehart, Winston, 1961). All titles selected from such bibliographies might be carefully screened by course instructors for content and by the librarians for revisions and new editions. The collection can be kept current by checking the Linguistic Bibliography (Heffer, 1950-), the annual lists in PMLA, and the book reviews in Language.

Joint responsibility for the development of the collection has proved most effective whenever subject comprehensiveness is desired and funds are plentiful. The faculty's specialized knowledge and research experience provides invaluable guidance for long-range planning

(Continued on page 2s2) 
formation retrieval will come to the junior college library as it will eventually come to all kinds of libraries. It is already being used experimentally in all kinds of libraries. In many cases, the information system will use the college computer. The fact that automation seems expensive should not retard its use. If library services are improved by automation, then the expense is worthwhile. Librarians have not always sought improved services as forcefully as they should. Of course, the sophistication to use such devices successfully must be developed, but the trend among junior college librarians to adopt audiovisual aids suggests a readiness to consider other devices also.

It seems clear that strong medicine is needed for these libraries. Perhaps this means strong federal support. Perhaps it means strong ACRL lobbying with college presidents. Perhaps it means a stronger breed of junior college librarians. At any rate, the future should be exciting.

\section{ACADEMIC STATUS . . .}

\section{(Continued from page 210$)$}

But "faculty," as understood by the great German universities that arose concomitant to and following the rise of the last, Leibnizian, type of academy, was Fach, "a discipline." To be a Fachmann was not regarded as anything other than to be a profess-or of a subject, a specialist. To what Fach then would the librarian belong except that of library science? But the librarian need not teach to be academic; indeed, to teach puts the librarian in a less secure academic position than to select or catalog books, etc. The library science faculty is no more proof against the charge of mere processing of students than any other teacher-less, in fact, due to the vocationalism of many such faculties.

Thus, within the faculty (Fach) are found ranks, the ordinary means of self- preservation of the alienated. The Fach is alienated within the universitas except by academic communing, which places the Fachmann on a new level, outside his narrow specialistic professionalism: the status of academician.

\section{EPILOGUE}

Academic status then, as viewed in the transparency of the situation, is a qualification added to that (for teachers) of faculty rank or to that (for librarians) of professional standing. It is not automatically predicated on either of these types of professional persons, but rather is a feature of the institution to which they belong. Like "standing," status implies a level, but not the discrete "I'm higher in rank than you," characteristic of faculty rank, but rather implies one level, the single plane of overt communing as determined by the nature and orientation of the institution. Such overt communing can take place only within the book environment which the librarian in a sense is. Without teaching, without even ever coming into personal contact with his fellow academicians, in an overt communing that can remain quite impersonal, the librarianas selector, cataloger, and servicer of the library-is the typical academic.

\section{BOOK SELECTION . . .}

(Continued from page 224)

of graduate facilities and resources. They are less reliable, however, when it comes to agreeing on the basic works in their field. You can get as many statements of what is essential and considered "standard" in each discipline as individuals you might wish to consult. Under these circumstances, it becomes the librarian's responsibility to acquaint the faculty with sound principles of book selection and a clear understanding of his acquisition problems and budgetary limitations. Only then is real cooperation possible. 